\title{
STUDIES ON HUMAN ALCAPTONURIA. EFFECT OF THIOURACIL, PARA-AMINOBENZOIC ACID AND DI-IODOTYROSINE ON EXCRETION OF HOMOGENTISIC ACID
}

\author{
By ABRAHAM G. WHITE, ${ }^{1}$ JULIUS G. PARKER, ${ }^{2}$ AND FRANK BLOCK
}

(From the Medical Division, Montefiore Hospital, New York City)

(Received for publication August 13, 1948)

The literature on alcaptonuria has been well summarized (1-6).

Paschkis et al. (7) reported that thiouracil and para-aminobenzoic acid inhibited the in vitro conversion of tyrosine to melanin by tryrosinase, and White (8) found that thiouracil inhibited melanuria. Lerner and associates (9) noted that the tyrosinase of mouse melanoma is a copper protein whose activity can be inhibited by the addition of substances which combine with copper (phenylthiourea and others) and then restored by the addition of an excess of copper. Since homogentisic acid is an oxidative product of tyrosine, it seemed worthwhile to determine whether the production of homogentisic acid could be inhibited by thiouracil and para-aminobenzoic acid. When 3, 5, diiodotyrosine is fed to rabbits, about $60 \%$ (Foster and Gutman [10]) is excreted as 3, 5, di-iodo4-hydroxyphenyllactic acid. It, therefore, occurred to us that, since the number 5 carbon on the benzene ring is blocked by iodine, the alcaptonuric patient would not be able to utilize di-iodotyrosine as he would 1-tyrosine to form homogentisic acid $(2,5$, dihydroxyphenylacetic acid $){ }^{3}$

Soderbergh (12) observed that the daily administration of $3.0 \mathrm{gm}$. of potassium iodide to an alcaptonuric decreased the urinary excretion of homogentisic acid by $2.0 \mathrm{gm}$. per day. This compound was administered to our patient in an attempt to influence similarly the excretion of homogentisic acid.

\section{EXPERIMENTAL}

The subject of our study was a 59-year-old white male, M.N., History No. 43082, who noted a blackish discolora-

\footnotetext{
1 Present address: Mount Sinai Hospital, New York City.

2 Resident in Medicine.

3 After this experiment had been completed, we learned that in 1907 Abderhalden, Bloch, and Rona (11) fed $2 \mathrm{gm}$. of 3,5 , di-iodotyrosine to an alcaptonuric without increasing the production of homogentisic acid.
}

tion of the ears 25 years ago, at which time it was observed that his urine became black on standing. Stiffness of almost all the joints occurred five years later.

Extensive laboratory examinations were essentially normal except for a blood uric acid of $6.8 \mathrm{mgm} . \%$ and the presence of homogentisic acid in the urine. The serological reactions for syphilis were negative.

Roentgenologic examinations were reported as follows. Spine: Marked hypertrophic changes were present. The intervertebral discs showed calcification, especially in the lumbar region. Pelvis: The right hip space was considerably narrowed and there was eburnation of the contiguous portions of the joint. Knees: There was calcification of the quadriceps tendons bilaterally. Hypertrophic changes were seen in both knee joints. Legs: Linear, irregular, and amorphous calcifications were seen in the soft tissues in the lower half of both legs. There was a mild osteoporosis of all bones. The ankles and feet showed no pathological changes. The changes described were considered characteristic of alcaptonuric ochronosis.

The genetic history of this patient is of interest. His parents were first cousins, neither of whom had alcaptonuria. The patient married a cousin who has no alcaptonuria. The presence of alcaptonuria and arthritis is indicated in Figure 1.

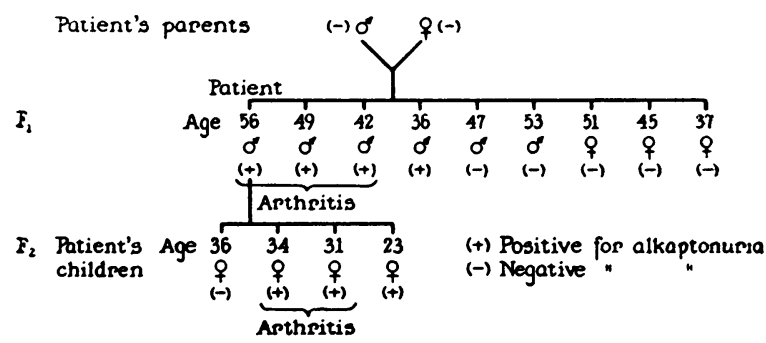

Fig. 1. Genetic History of Alcaptonuric Patient Who Was Subject of Present Study

The effect of thiouracil and para-aminobenzoic acid on the urinary excretion of homogentisic acid was determined. In addition, the effects of potassium iodide, diiodotyrosine and 1-tyrosine were also observed.

Period 1: Control period of seven days. Period 2: Thiouracil $0.2 \mathrm{gm}$. t.i.d. was administered for 12 days. Period 3: Para-aminobenzoic acid was then given in doses of $4 \mathrm{gm}$., five times a day, with 30 c.c. of $5 \%$ $\mathrm{NaHCO}_{3}$ accompanying each dose, for seven days. $\mathrm{Pe}$ - 
TABLE I

\begin{tabular}{|c|c|c|c|}
\hline Period & $\begin{array}{c}\text { Day of } \\
\text { experiment }\end{array}$ & $\begin{array}{c}\text { Urine } \\
\text { volume }\end{array}$ & $\begin{array}{l}\text { Homogentisic } \\
\text { acid }\end{array}$ \\
\hline Control & $\begin{array}{l}1 \\
2 \\
3 \\
4 \\
5 \\
6 \\
7 \\
\text { Daily }\end{array}$ & $\begin{array}{c}\text { c.c./24 hours } \\
1695 \\
1560 \\
1240 \\
2580 \\
1690 \\
2330 \\
1650 \\
\text { verage for } p\end{array}$ & $\begin{array}{c}\mathrm{gm} . / 24 \text { hours } \\
4.41 \\
4.84 \\
3.60 \\
4.89 \\
4.56 \\
6.76 \\
3.80 \\
\text { iod } 4.69\end{array}$ \\
\hline $\begin{array}{c}\text { II } \\
\text { Thiouracil } \\
0.2 \text { gm., t.i.d. }\end{array}$ & $\begin{array}{l}8 \\
9 \\
10 \\
11 \\
12 \\
13 \\
14 \\
15 \\
16 \\
17 \\
18 \\
19 \\
\text { Daily }\end{array}$ & $\begin{array}{c}1320 \\
1320 \\
1810 \\
2380 \\
1580 \\
1750 \\
1750 \\
1850 \\
1120 \\
1950 \\
1380 \\
1180 \\
\text { verage for }\end{array}$ & $\begin{array}{l}4.88 \\
4.88 \\
5.07 \\
5.48 \\
4.74 \\
4.16 \\
4.16 \\
4.44 \\
3.70 \\
5.27 \\
3.31 \\
4.25 \\
\text {-iod } 4.53\end{array}$ \\
\hline $\begin{array}{c}\text { III } \\
\text { Para- } \\
\text { aminobenzoic } \\
\text { acid } \\
201 \mathrm{gm} . / \text { day }\end{array}$ & $\begin{array}{l}20 \\
21 \\
22 \\
23 \\
24 \\
25 \\
26 \\
\text { Daily }\end{array}$ & $\begin{array}{c}1840 \\
1850 \\
1630 \\
1995 \\
1735 \\
1950 \\
1325 \\
\text { verage for } \mathrm{F}\end{array}$ & $\begin{array}{r}4.23 \\
4.81 \\
4.08 \\
4.99 \\
4.86 \\
5.46 \\
4.24 \\
\text { iod } 4.67\end{array}$ \\
\hline $\begin{array}{c}\text { IV } \\
\text { Control }\end{array}$ & $\begin{array}{l}27 \\
28 \\
29 \\
30 \\
31 \\
\text { Daily }\end{array}$ & $\begin{array}{c}1140 \\
1460 \\
1510 \\
1290 \\
1090 \\
\text { verage for }\end{array}$ & $\begin{array}{r}4.33 \\
4.09 \\
3.62 \\
4.26 \\
3.14 \\
\text { riod } 4.09\end{array}$ \\
\hline $\begin{array}{c}\mathrm{V} \\
\text { Potassium iodide } \\
2.0 \mathrm{gm} . / \mathrm{day}\end{array}$ & $\begin{array}{l}32 \\
33 \\
34 \\
\text { Daily }\end{array}$ & $\begin{array}{c}1860 \\
1040 \\
2030 \\
\text { verage for } F\end{array}$ & $\begin{array}{r}5.21 \\
3.64 \\
4.87 \\
\text { riod } 4.57\end{array}$ \\
\hline $\begin{array}{l}\text { VI } \\
\text { Potassium iodide } \\
4.0 \mathrm{gm} . / \mathrm{day}\end{array}$ & $\begin{array}{l}35 \\
36 \\
37 \\
38 \\
\text { Daily }\end{array}$ & $\begin{array}{c}1700 \\
1715 \\
1580 \\
1460 \\
\text { verage for }\end{array}$ & $\begin{array}{r}3.91 \\
3.60 \\
4.42 \\
3.50 \\
\text { riod } 3.86\end{array}$ \\
\hline $\begin{array}{c}\text { VII } \\
\text { 3,5,di- } \\
\text { iodotyrosine } \\
8.0 \mathrm{gm} . / \mathrm{day}\end{array}$ & $\begin{array}{l}39 \\
40 \\
41 \\
42 \\
43 \\
\text { Daily }\end{array}$ & $\begin{array}{c}1270 \\
1480 \\
1385 \\
1480 \\
1310 \\
\text { verage for }\end{array}$ & $\begin{array}{r}3.94 \\
4.44 \\
5.40 \\
6.36 \\
4.45 \\
\text { riod } 4.92\end{array}$ \\
\hline $\begin{array}{c}\text { VIII } \\
\text { l-tyrosine } \\
8.0 \mathrm{gm} . / \text { day }\end{array}$ & $\begin{array}{l}44 \\
45 \\
46 \\
47 \\
48 \\
\text { Dail }\end{array}$ & $\begin{array}{c}1610 \\
1380 \\
1410 \\
1810 \\
1720 \\
\text { rerage for }\end{array}$ & $\begin{array}{r}4.99 \\
7.87 \\
8.88 \\
8.69 \\
9.46 \\
\text { riod } 7.98\end{array}$ \\
\hline
\end{tabular}

* 48-hour urine collection and homogentisic acid output expressed per 24 hours. riod 4: Control period of five days. Period 5: $2.0 \mathrm{gm}$. of potassium iodide per day were given orally as a $50 \%$ solution for three days. Period 6: $4.0 \mathrm{gm}$. of potassium iodide per day were given orally as a $50 \%$ solution for four days. Period 7: $8.0 \mathrm{gm}$. daily of di-iodotyrosine were given orally as a powder in four divided doses of $2.0 \mathrm{gm}$. each for five days. Period 8: $8.0 \mathrm{gm}$. daily of 1-tyrosine were given orally as a powder in four divided doses of $2.0 \mathrm{gm}$. each for five days.

The daily diet during the entire period contained approximately $70 \mathrm{gm}$. protein and 1800 calories.

\section{METHODS}

Twenty-four-hour urine specimens were collected and preserved with approximately 10 c.c. concentrated $\mathrm{HCl}$ so that all specimens remained acid to congo red.

Homogentisic acid was determined quantitatively by the iodometric method as described by Lieb and Lanyar (13).

\section{RESULTS AND DISCUSSION}

Results are presented in Table I and Figure 2.

The average daily excretions of homogentisic acid in the control periods, 4.69 and $4.09 \mathrm{gm}$., agree well with the value of $4.65 \mathrm{gm}$. observed by Neuberger (5) in a patient receiving $60 \mathrm{gm}$. of protein daily.

Thiouracil and para-aminobenzoic acid did not inhibit the excretion of homogentisic acid since the average daily excretion was $4.53 \mathrm{gm}$. and $4.67 \mathrm{gm}$. for the respective periods. It, therefore, seems that the oxidative enzymes involved in the conversion of tyrosine to homogentisic acid are not similar to the tyrosinase concerned with the oxidation of tyrosine to melanin.

When $8.0 \mathrm{gm}$. of 1-tyrosine were administered, the average daily excretion for this period was 7.98 gm. as compared with $4.09 \mathrm{gm}$. for the preceding control period. The difference, 3.89 gm., represents a conversion of $52.6 \%$. Mittelbach (14) observed a low percentage of conversion to homogentisic acid when $15.0 \mathrm{gm}$. of 1-tyrosine were given. This is in contrast with the $80 \%$ to $85 \%$ conversion of $3.0 \mathrm{gm}$. of 1-phenylalanine observed by Neuberger (5).

Despite the large amounts ( $8.0 \mathrm{gm}$. daily) of 3,5 , di-iodotyrosine administered to our patient, the average daily excretion of homogentisic acid was 4.92 , and this did not differ markedly from the control excretions. This would indicate an inability of the alcaptonuric to convert this compound to homogentisic acid.

Foster and Gutman (10) found that when 3, 5, di-iodotyrosine was fed to rabbits, about $60 \%$ was 


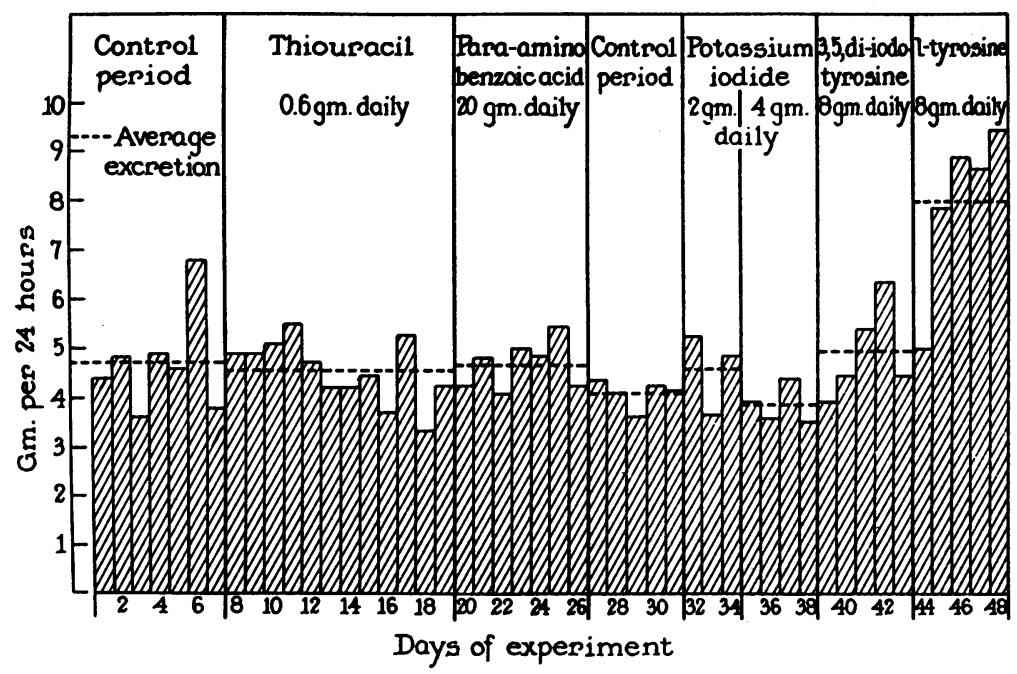

Fig. 2. The Excretion of Homogentisic Acid in Grams per 24-hour Periods under Various Experimental Conditions

The amount of homogentisic acid is represented to the nearest tenth of a gram.

excreted as 3, 5, di-iodo-4-hydroxyphenyllactic acid. We did not expect this portion to be converted to homogentisic acid by our patient because the number 5 carbon was blocked by iodine. However, the remaining $40 \%$, representing $3.2 \mathrm{gm}$. of the daily $8.0 \mathrm{gm}$. dose administered, might be available for conversion to homogentisic acid. This did not happen.

Soderbergh (12) observed that when an alcaptonuric patient was given $3.0 \mathrm{gm}$. of potassium iodide daily, the urinary output of homogentisic acid decreased to $6.50 \mathrm{gm}$. daily from a control level of $8.50 \mathrm{gm}$. We did not find any decrease in our patient.

\section{CONCLUSIONS}

1. An alcaptonuric patient on an approximately $70 \mathrm{gm}$. daily protein basal diet excreted a daily average of $4.69 \mathrm{gm}$. and $4.09 \mathrm{gm}$. of homogentisic acid during two control periods of seven days and five days respectively.

2. Thiouracil and para-aminobenzoic acid did not reduce the excretion of homogentisic acid.

3. $8.0 \mathrm{gm}$. daily of 1-tyrosine yielded an average daily excretion of $7.98 \mathrm{gm}$. of homogentisic acid, which represented a conversion of $52.6 \%$.

4. $8.0 \mathrm{gm}$. daily of 3,5 , di-iodotyrosine resulted in an average daily excretion of $4.92 \mathrm{gm}$. of homogentisic acid, essentially the control level.
5. Potassium iodide in doses of $2.0 \mathrm{gm}$. and $\mathbf{4 . 0}$ gm. daily did not decrease the urinary excretion of homogentisic acid.

6. The oxidative enzymes involved in the conversion of tyrosine to homogentisic acid differ in their lack of response to thiouracil from the tyrosinase which produces melanin.

\section{ACKNOWLEDGMENT}

We wish to extend our thanks for the advice and encouragement given by Dr. Louis Leiter, Chief of the Medical Division, Montefiore Hospital.

\section{BIBLIOGRAPHY}

1. Garrod, A. E., Inborn Errors of Metabolism. H. Frowde, Hodder and Stoughton, London, 1923, Ed. 2.

2. Peters, J. P., and Van Slyke, D. D., Quantitative Clinical Chemistry, Vol. I. Williams \& Wilkins, Baltimore, 1946, Ed. 2.

3. Duncan, G. G., Diseases of Metabolism. W. B. Saunders Company, Philadelphia and London, 1942.

4. Neuberger, A., Studies on alcaptonuria. I. The estimation of homogentisic acid. Biochem. J., 1947, 41, 431.

5. Neuberger, A., Rimington, C., and Wilson, J. M. G., Studies on alcaptonuria. II. Investigations on a case of human alcaptonuria. Biochem. J., 1947, 41, 438.

6. Neuberger, A., and Webster, T. A., Studies on alcaptonuria. III. Experimental alcaptonuria in rats. Biochem. J., 1947, 41, 449. 
7. Paschkis, K. E., Cantarow, A., Hart, W. M., and Rakoff, A. E., Inhibitory action of thiouracil, thiocarbamide and other compounds on melanin formation by tyrosinase. Proc. Soc. Exper. Biol. \& Med., 1944, 57, 37.

8. White, A. G., Effect of tyrosine, tryptophane, and thiouracil on melanuria. J. Lab. \& Clin. Med., 1947, 32, 1254.

9. Lerner, A. B., Fitzpatrick, T. B., Calkins, E., and Summerson, W. H., Enzymatic oxidation of tyrosine and dihydroxyphenylalanine by melanoma extracts. Federation Proc., 1948, 7, 167.

10. Foster, G. L., and Gutman, A. B., On the fate of di-iodotyrosine in the animal organism. J. Biol. Chem., 1930, 87, 289.
11. Abderhalden, E., Bloch, B., and Rona, P., Abbau einiger Dipeptide des Tyrosins und Phenylalanins bei einem Falle von Alkaptonurie. Ztschr. f. physiol. Chem., 1907, 52, 435.

12. Soderbergh, G., Zur Klinik der Alkaptonurie, insbesondere über die Wasserman'sche Reaktion und Ostitis deformans Alkaptonurica. Nord. Med. Arkiv., 1915, Afd II, Haft 4, 1.

13. Lieb, H., and Lanyar, F., Uber die Jodometrische Bestimmung der Homogentisinsäure im Harn. Ztschr. f. physiol. Chem., 1929, 181, 199.

14. Mittelbach, F., Ein Beitrag zur Kenntnis der Alkaptonurie. Deutsches Arch. f. klin. Med., 1901, 71, 50. 